\title{
Management proposal based on the timing of oral incubation of eggs and juveniles in the sentinel species Genidens genidens (Siluriformes: Ariidae) in a tropical estuary
}

\author{
Thaís Rodrigues Maciel ${ }^{1}$, André Martins Vaz-dos-Santos², Erica Pellegrini Caramaschi ${ }^{3}$ \\ and Marcelo Vianna ${ }^{1}$
}

Ariids such as Genidens genidens are particularly susceptible to overfishing because of their complex reproductive mechanisms, which result in slow replenishment of stocks. In this study, we obtained data about the reproductive ecology of the catfish $G$. genidens in the Guanabara Bay estuary, Rio de Janeiro, Brazil, providing supporting information for management of its fishery. The sex ratio, mean size of each sex at first sexual maturation, and female fecundity were determined and the reproductive period was characterized. The males:females ratio was 1:2. The fecundity is low and increases proportionally to the females' growth in total length and weight. The breeding season occurs during the warmest months of the year, with spawning extending from October through March and incubation from December through April. Sexual maturation is late, with males maturing at a larger size than females. Skipping spawning was also identified in females. Based on the reproductive biology, it is suggested that the catch be restricted to individuals larger than $20 \mathrm{~cm}$, considering the $\mathrm{L}_{75}$ of the males, and that fishing be prohibited from December through March, to include the main period of spawning season by females and oropharyngeal incubation by males.

Keywords: Catfish, Fishery management, Guanabara Bay, Parental care, Reproductive strategy.

Arí́deos, como Genidens genidens, são particularmente suscetíveis à sobrepesca devido a seus complexos mecanismos reprodutivos, que resultam em uma reposição lenta dos estoques. Neste estudo, obtivemos dados sobre a ecologia reprodutiva do bagre G. genidens no estuário da Baía de Guanabara, Rio de Janeiro, Brasil, fornecendo subsídios para seu manejo pesqueiro. A proporção sexual, o tamanho médio de primeira maturação sexual de cada sexo e a fecundidade das fêmeas foram determinados e o período reprodutivo caracterizado. A proporção machos:fêmeas foi de 1:2. A fecundidade é baixa e aumenta proporcionalmente ao crescimento das fêmeas em comprimento total e no peso. O período reprodutivo ocorre durante os meses mais quentes do ano, com a desova se estendendo de outubro a março e a incubação de dezembro a abril. A maturação sexual é tardia, com machos amadurecendo em tamanho maior que as fêmeas. Também foi identificado nas fêmeas adiamento da desova. Com base na biologia reprodutiva, sugere-se que a captura seja restrita a indivíduos maiores que $20 \mathrm{~cm}$, considerando a $\mathrm{C}_{75}$ dos machos, e que a pesca seja proibida de dezembro a março, para incluir o período principal de época de desova das fêmeas e incubação orofaríngea dos machos.

Palavras-chave: Bagres, Baía de Guanabara, Cuidado parental, Estratégia reprodutiva, Gestão pesqueira.

\section{Introduction}

In tropical and subtropical regions, catfishes of the Ariidae family occur in marine, estuarine and freshwater environments, usually in shallow coastal waters with mud bottoms (Araújo, 1988; Azevedo et al., 1999; Schmidt et al., 2008; Silva Junior et al., 2013). Estuarine and coastal regions are especially important areas for breeding, feeding and growth (Araújo, 1988; Schmidt et al., 2008; Silva Junior et al., 2013, 2016; Maciel et al., 2018). Food and Agriculture Organization of the United Nations (FAO) data describe landings of 49,600 to 72,900 tons of ariids in the Western Central Pacific and 14,885 to 26,630 tons in the Western Central Atlantic from 1995 through 1999 (Kailola, 1999;

\footnotetext{
${ }^{1}$ Laboratório de Biologia e Tecnologia Pesqueira, Universidade Federal do Rio de Janeiro, Av. Carlos Chagas Filho, 373, 21941-541 Rio de Janeiro, RJ, Brazil. (TRM) thaisrmaciel@gmail.com, Dhttps://orcid.org/0000-0002-5336-5607 (corresponding author), (MV) mvianna@ biologia.ufrj.br

${ }^{2}$ Laboratório de Esclerocronologia, Universidade Federal do Paraná, Rua Pioneiro, 2153, Jardim Dallas, $85950-000$ Palotina, PR, Brazil. andrevaz@gmail.com

${ }^{3}$ Laboratório de Ecologia de Peixes, Universidade Federal do Rio de Janeiro, Av. Carlos Chagas Filho, 373, $21941-541$ Rio de Janeiro, RJ, Brazil. erica.caramaschi@gmail.com
} 
Acero, 2002). In Brazil, ariid catfishes are widely distributed along the coast and have high economic importance for artisanal fisheries, especially in estuaries (Gomes, Araújo, 2004; Silva Junior et al., 2013).

One of the most common species of Ariidae is the catfish Genidens genidens (Cuvier, 1829), which occurs on the eastern coast of South America, from the Guianas $\left(8^{\circ} 40^{\prime} \mathrm{N}\right)$ to the Río de La Plata, Argentina ( $35^{\circ} 95^{\prime} \mathrm{S}$ ) (Marceniuk, Menezes, 2007). This species is especially abundant in estuaries and coastal lagoons (Andrade-Tubino et al., 2008; Schmidt et al., 2008; Silva Junior et al., 2013). This great abundance and the estuarine-resident behavior caused $G$. genidens to be selected as a sentinel species to monitor the environmental quality of Guanabara Bay (Silva Junior et al., 2013), which makes the study of its biology a priority. Guanabara Bay is a tropical estuary of high social, economic and environmental importance (Silva Junior et al., 2013; Begot, Vianna, 2014; Prestrelo, Vianna, 2016; Silva Junior et al., 2016). Even though this bay is considered the most degraded estuarine system on the Brazilian coast (Meniconi et al., 2012), it still maintains the essential ecological characteristics to harbor a diversified ichthyofauna (Andrade et al., 2015; Corrêa, Vianna, 2016; Silva Junior et al., 2016), supporting the most productive estuarine fishery in the region (Prestrelo, Vianna, 2016).

The reproductive ecology of the Ariidae is peculiar, considering the fishes sexual plasticity (Pandian, 2010). The family includes demersal fish, whose males incubate the eggs and embryos in the oropharyngeal cavity (Wootton, 1990; Hostim-Silva et al., 2009; Silva Junior et al., 2013; Paiva et al., 2015). Similarly to all other Ariidae, G. genidens is particularly susceptible to overfishing because of its complex reproductive mechanisms, which result in slow stock replenishment (King, 1995). Therefore, the management of the $G$. genidens fishery is based on obtaining reliable population data, since the peculiarities of their reproductive behavior make these fish highly dependent on population density (e.g. Chaves, 1994).

The goal of conventional fishery management is to regulate fishing mortality of a given stock in a way that produces sustainable, near-maximum yields (O'Farrell, Botsford, 2006). However, the factors that affect reproductive success and resilience in exploited marine fish are extremely complex and poorly understood, and not all these factors can be managed (Lowerre-Barbieri et al., 2016). There is growing awareness that we need to better understand the species' reproductive biology and its effects on recruitment. The reproductive success of a species is determined by the probability that the offspring will survive to reproductive age, on the basis of reproductive production and the survival of the young (Stearns, 1992; Lowerre-Barbieri et al., 2016). Studies on the ecology of teleost reproductive processes make it possible to understand not only the mechanisms that enable the perpetuation of the species, but also their vulnerability to overfishing and the evolution induced by fishing pressure (Dias et al., 1998; Lowerre-Barbieri et al., 2016).
Knowledge of biological variables such as adult abundance, sex ratio, spawning areas and period, fecundity, and number of eggs and larvae of a species is essential for use in predictive models applied to managing the fishery (Dias $e t$ al., 1998; Lowerre-Barbieri et al., 2016). The mean length at first gonadal maturity is also an important parameter for population management, as it guides the determination of the minimum catch and net mesh sizes (e.g. King, 1995; Vazzoler, 1996).

In this study we acquired objective data on the reproductive ecology of the catfish G. genidens in the Guanabara Bay estuary, for the purpose of fishery management. This contributes to a tropical estuarine fishery that is still lacking in information to enable proper management (Blaber, 2013), and which should be defined by specific legal regulations according to the biological characteristics of the populations in each region (Begot, Vianna, 2014).

\section{Material and Methods}

Study area. Guanabara Bay (Fig. 1), the second-largest bay on the Brazilian coast (Meniconi et al., 2012), is located in the state of Rio de Janeiro, at $22^{\circ} 50^{\prime} \mathrm{S}$ and $043^{\circ} 10^{\prime} \mathrm{W}$, with an area of $384 \mathrm{~km}^{2}$, mean water volume of $1.87 \times 109 \mathrm{~m}^{3}$ and maximum depth of $50 \mathrm{~m}$ at the bay entrance (Kjerfve $e t$ al., 1997). The climate is tropical-humid, with a warm rainy season (December through March) and a cold dry season (July through August) (Castro et al., 2005). This estuary is important socioeconomically and supports a productive fishery (Meniconi et al., 2012; Begot, Vianna, 2014; Prestrelo, Vianna, 2016). It is extremely degraded, due to large inputs of untreated solid waste, organic matter, heavy metals and hydrocarbons from a densely populated area, with about 11 million inhabitants and approximately 10,000 industries, as well as intense port activity and a petrochemical hub (Meniconi et al., 2012; Silva Junior et al., 2016).

Biological sampling. Specimens of G. genidens were obtained biweekly from artisanal fishery landings, with different types of fishing gear, from January 2014 to January 2015, in the localities of Paquetá, Bancários and Magé. In order to improve the sampling of small individuals, experimental sampling was conducted monthly at two stations in the bay, one near Fundão Island and the other in the central channel (Fig. 1), where, in each month, 30-min bottom trawls were conducted. The collected catfish were stored on ice for transport to the laboratory. Specimens were deposited in the collection of the Museu Nacional, Rio de Janeiro, Brazil (Voucher specimens: MNRJ 42040).

In the laboratory, the fishes were measured (total length $-\mathrm{Lt}, \mathrm{cm}$ ) and weighed individually with an electronic balance (total weight - Wt, g). An incision was made in the abdominal region for inspection, removal and weighing of the gonads (gonad weight $-\mathrm{Wg}$, g). The gonadal development stages of males and females were identified macroscopically, considering oocyte size (for females), color, vascu- 


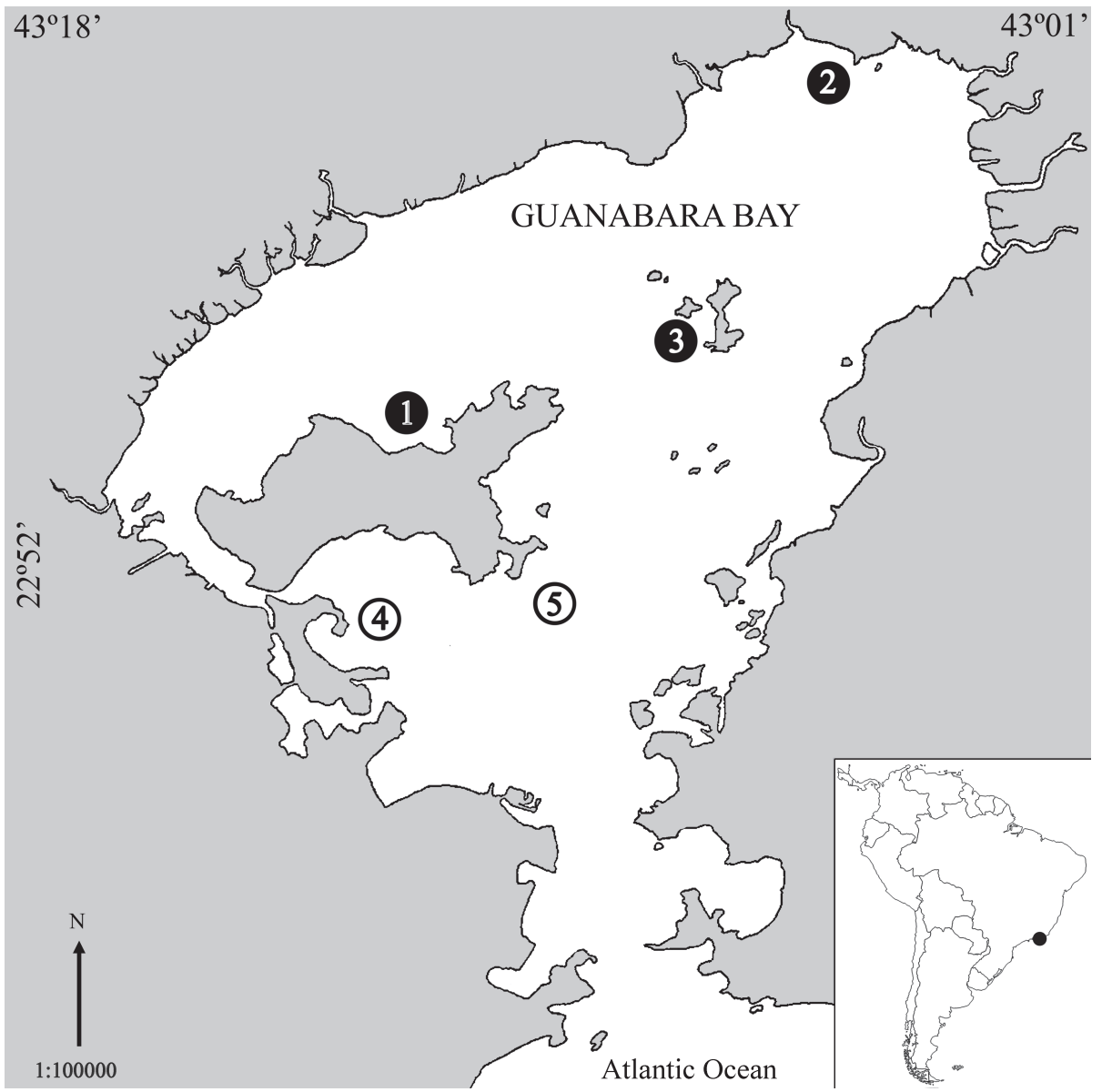

Fig. 1. Guanabara Bay, Rio de Janeiro, Brazil, indicating the sampling stations: 1- Bancários, 2- Magé, 3- Paquetá Island, 4Fundão Island, 5- central channel. Black circles indicate artisanal fishing landing sites and white circles indicate experimental sampling sites.

larization, and percentage of abdominal-cavity occupancy. The gonad stages were classified as immature, developing, spawning-capable, regressing, and regenerating, as proposed by Brown-Peterson et al. (2011). For the fecundity analyses, the total number of hydrated vitellogenic oocytes (ready-to-spawn), recognized by their translucent appearance, was counted from each pair of gonads classified as spawning-capable (Vazzoler, 1996).

For small individuals for which macroscopic analysis of the gonads was inconclusive, the classification was later confirmed by histological analysis (Vazzoler, 1996). The gonads were fixed in $20 \%$ buffered formaldehyde and preserved in $70 \%$ ethanol. They were then gradually dehydrated and embedded in histological resin, cross-sectioned in 5 $\mu \mathrm{m}$-thick sections, and stained with hematoxylin-eosin. The sections were observed under an optical microscope, and the stages of gonadal maturation were determined according to the development stage of the germ cells. Immature ovaries were characterized by the presence of only oogonia and oocytes in primary growth, with little space between the oocytes; and immature testes by a predominance of primary, non-organized spermatogonia in the seminiferous tubules (Brown-Peterson et al., 2011).
Data analysis. The monthly sex ratio was compared to the expected ratio of 1:1 with the chi-square test $\left(\chi^{2} ; \alpha=0.05\right)$ and Yates correction (Zar, 2010). To characterize the reproductive cycle and determine the spawning period, the relative frequency of individuals at different gonadal development stages, and the monthly mean values of the gonadosomatic index (GSI) and gonad condition factor $(\Delta \mathrm{K})$ were calculated for each sex separately (Vazzoler, 1996; Hostim-Silva et al., 2009), GSI $=(\mathrm{Wg} / \mathrm{Wt}) \times 100$, where: $\mathrm{Wg}=$ gonad weight and $\mathrm{Wt}=$ total weight and $\Delta \mathrm{K}=(\mathrm{Wg} /$ $\left.\mathrm{Lt}^{b}\right) \times 10^{5}$, where: $\mathrm{Wg}=$ gonad weight, $\mathrm{Lt}=$ total length, and $b=$ the angular coefficient of the length-weight relationship, that was adjusted by the least-squares method (Zar, 2010). Juveniles were removed from the GSI and $\Delta \mathrm{K}$ analyzes, but maintained in the analysis of frequency of the gonadal development stages to illustrate the recruitment period. After assumptions checking, the monthly series of GSI and $\Delta \mathrm{K}$ values were compared with a Kruskal-Wallis test followed by a Mann-Whitney test for pairwise comparisons (Zar, 2010). We also calculated the monthly frequency of adult males incubating eggs and juveniles in order to define parental care period. The relationships between the length or weight of males and the number or weight of eggs and ju- 
veniles that they were incubating were determined and adjusted using the least-squares method (Zar, 2010).

To estimate the transition from the juvenile to the adult status, individuals were classified as young (immature) or adult (all other gonadal maturation stages) from the histological analyses of the gonads. The proportion of mature individuals per size class $(P)$ was calculated, estimating the mean size at first gonadal maturation $\left(\mathrm{L}_{50}\right)$ and applying a logistic curve according to the method of King (1995). The $P$ values were estimated using the parameters $a$ and $b$ of the regression. The $\mathrm{L}_{50}$ was calculated from the ratio of $a:-b$. The $\mathrm{L}_{25}$, $\mathrm{L}_{75}$ and $\mathrm{L}_{100}$ values were calculated based on the estimated $P$ ' values of the logistic curve, from the following mathematical expression (King, 1995): $P^{\prime}=1 /\left\{1+\mathrm{e}^{[-\mathrm{r}(\mathrm{Lt}-\mathrm{L} 50)]}\right\}$, where, $P^{\prime}=$ proportion of adult individuals expected in the length class $(\mathrm{Lt}), r=-b$ and $\mathrm{Lt}=$ total length class. The parameters $a, b$ and $\mathrm{L}_{50}$ were adjusted by the least-squares method (Zar, 2010). In addition, to evaluate the maturation of females we calculated the relative frequency of females at each stage of gonadal maturation by length class (intervals of $2 \mathrm{~cm}$ ).

Absolute fecundity was calculated as the mean number of oocytes released per female during the spawning period (Vazzoler, 1996). The relationships between fecundity (F) and total length, total weight, and gonad weight were determined (Pandian, 2010). The residues from the initial adjustment were removed and the coefficients recalculated using the least-squares method (Zar, 2010).

\section{Results}

A total of 1,107 individuals of $G$. genidens were collected, with total lengths ranging from 5 to $47 \mathrm{~cm}$, including 377 males and 730 females (sex ratio 1:2). The number of females was higher than that of males in the months of June, July, September, November, December and January (Fig. 2).

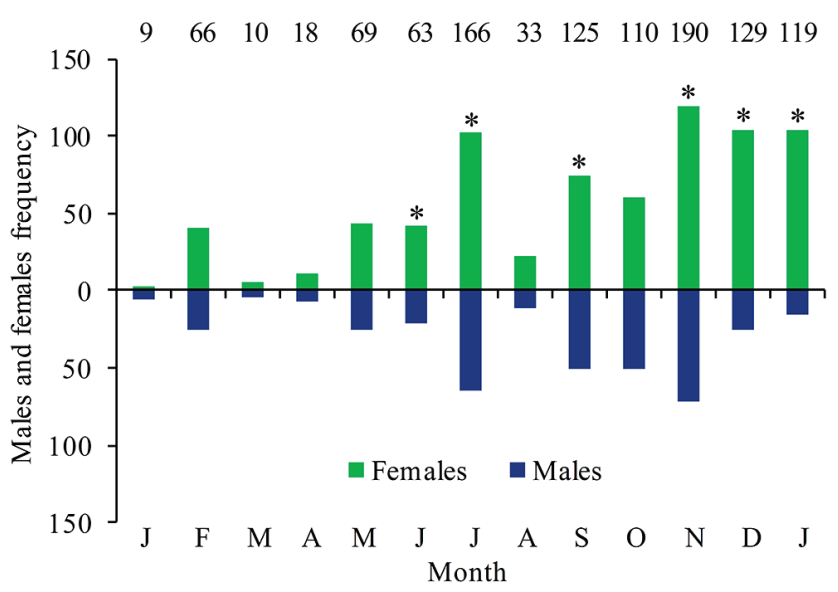

Fig. 2. Monthly distribution of Genidens genidens males and females in Guanabara Bay, Rio de Janeiro, Brazil from January 2014 to January 2015 . The values at the top indicate the number of individuals caught each month. (*) Significant difference $(p<0.05)$.
We observed males and females in all five stages of gonad development and the monthly proportion varied in both sexes (Fig. 3). From September on, the number of females with developing gonads increased, and the number of females with regenerating gonads decreased. Males and females with spawning-capable gonads were captured from October through March. A similar pattern was apparent for the GSI, which was higher from November through March in females and from December through March in males, indicating that this species reproduces in the warmer period, from spring to summer. Monthly values of GSI showed significant differences both for males $(\mathrm{H}=149.4, p<0.001)$ and females $(\mathrm{H}=465.5, p<0.001)$, related to those periods with remarkable differences $(p<0.05$ in the pairwise Mann-Whitney tests). A predominance of females with regenerating gonads extended from April through August. In addition, individuals with developing gonads were caught throughout the year.

The highest $\Delta \mathrm{K}$ values of the females $(\mathrm{H}=453.0$, $p<0.001)$ and males $(\mathrm{H}=137.9, p<0.001)$ coincided with the months of higher frequency of gonads capable of spawning (Figs. 3-4). The months whose $\Delta \mathrm{K}$ values showed remarkable differences also presented statistical differences $(p<0.05$ in the pairwise Mann-Whitney tests).

Males incubating eggs $(\mathrm{N}=10)$ were recorded from December through March, and males incubating juveniles $(\mathrm{N}=3)$ from January through April (Fig. 4). Both eggs and juveniles incubated by the same male were in similar stages of development. The smallest incubating male caught measured $22 \mathrm{~cm}$, and the largest $38 \mathrm{~cm}$. Individual males incubated 1 or 2 juveniles and 4 to 25 eggs (mean 10.6 eggs per male). No linear relationships were observed between the length or weight of males and the number or weight of eggs and the number of juveniles incubated. However, the juveniles weight was higher when incubated by larger and heavier males (Tab. 1). Fig. 5 shows the reproductive cycle of the species throughout the year based on spawning and parental care period.

The calculated values of $\mathrm{L}_{25}, \mathrm{~L}_{75}, \mathrm{~L}_{50}$ and $\mathrm{L}_{100}$ for females were $15.2 \mathrm{~cm}, 15.9 \mathrm{~cm}, 16.6 \mathrm{~cm}$ and $19.3 \mathrm{~cm}$, and for males $15.3 \mathrm{~cm}, 17.6 \mathrm{~cm}, 19.8 \mathrm{~cm}$ and $28.2 \mathrm{~cm}$ respectively (Fig. 6).

Although all females became adults at about $19 \mathrm{~cm}$, females with gonads capable of spawning were only observed from $20 \mathrm{~cm}$ and above (Fig. 7), indicating that these smaller individuals are reabsorbing the oocytes produced. This supposition was confirmed by the histological analysis of the gonads, where atretic follicles and yellow bodies were present in the ovaries of adult females smaller than $20 \mathrm{~cm}$ (Fig. 8).

The absolute fecundity was 25 oocytes per female (minimum 8 , maximum 52). A more pronounced increase in female mean fecundity was observed from $28 \mathrm{~cm}$ and above (Fig. 9a). The number of eggs produced per female showed linear and potential relationship with de total length increase and total weight increase, respectively, but low relationship to the increase in the weight of the gonads (Fig. 9). 


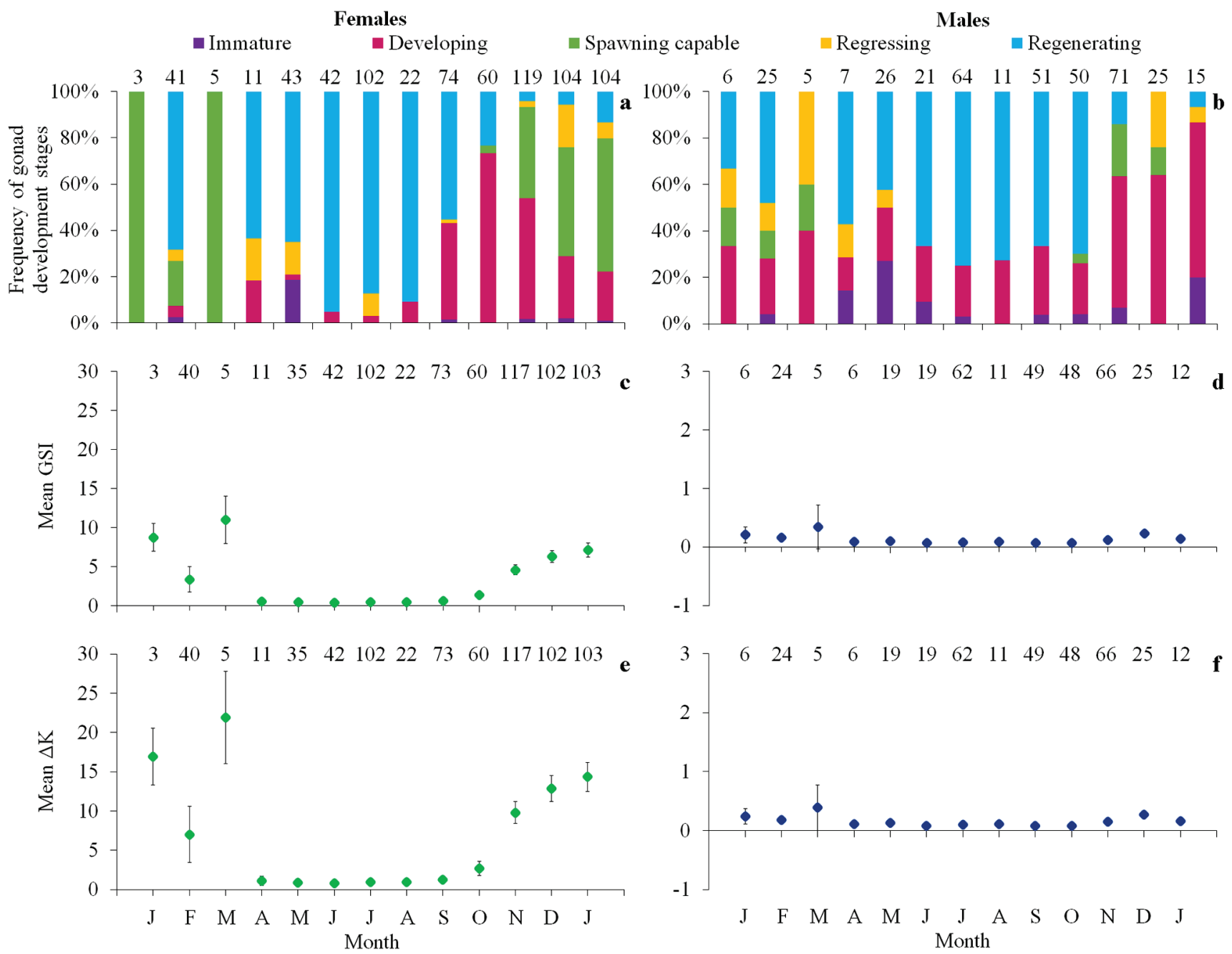

Fig. 3. Monthly distribution of the gonad development stages, GSI (mean $\pm \mathrm{CI}$ ) and $\Delta \mathrm{K}$ (mean $\pm \mathrm{CI}$ ) of Genidens genidens females and males in Guanabara Bay, Rio de Janeiro, Brazil from January 2014 to January 2015. a. frequency of gonad development stages of females $(\mathrm{N}=730)$; $\mathbf{b}$. frequency of gonad development stages of males $(\mathrm{N}=377)$; $\mathbf{c}$. females GSI $(\mathrm{N}=$ 715); d. males GSI $(\mathrm{N}=352)$; e. females $\Delta \mathrm{K}(\mathrm{N}=715)$; f. males $\Delta \mathrm{K}(\mathrm{N}=352)$. The values at the top of the graphs indicate the number of individuals caught each month. The juveniles were excluded from GSI and $\Delta \mathrm{K}$ analyzes.

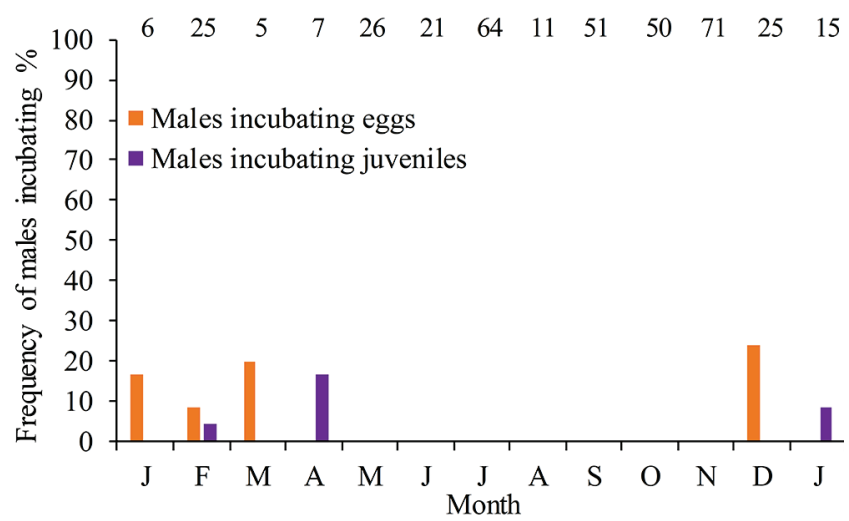

Fig. 4. Monthly distribution of the relative frequency (\%) of Genidens genidens males $(\mathrm{N}=377)$ performing oral incubation of eggs and juveniles in Guanabara Bay, Rio de Janeiro, Brazil from January 2014 to January 2015. The values at the top indicate the total number of adult males caught each month.

\section{Discussion}

This study confirmed the reproductive cycle of G. genidens occurred completely within the Guanabara Bay estuary, reinforcing the estuarine-resident character attributed to this population (Silva Junior et al., 2013). The length structure and the presence of fish in all stages of development, as well as individuals in reproductive activity, demonstrated that the species does not depend on other adjacent environments to complete its life cycle (Elliott et al., 2007).

In the Guanabara Bay estuary, the number of females of G. genidens exceeded that of males. This pattern seems to be related to resident estuarine populations that travel between the upper, middle and lower estuaries, as was previously observed for G. genidens in Guanabara Bay (Silva Junior et al., 2013) and in Sepetiba Bay, another tropical estuary, approximately $305 \mathrm{~km}^{2}$ in area (Gomes et al., 1999). However, in smaller more heterogeneous environments the proportion of 


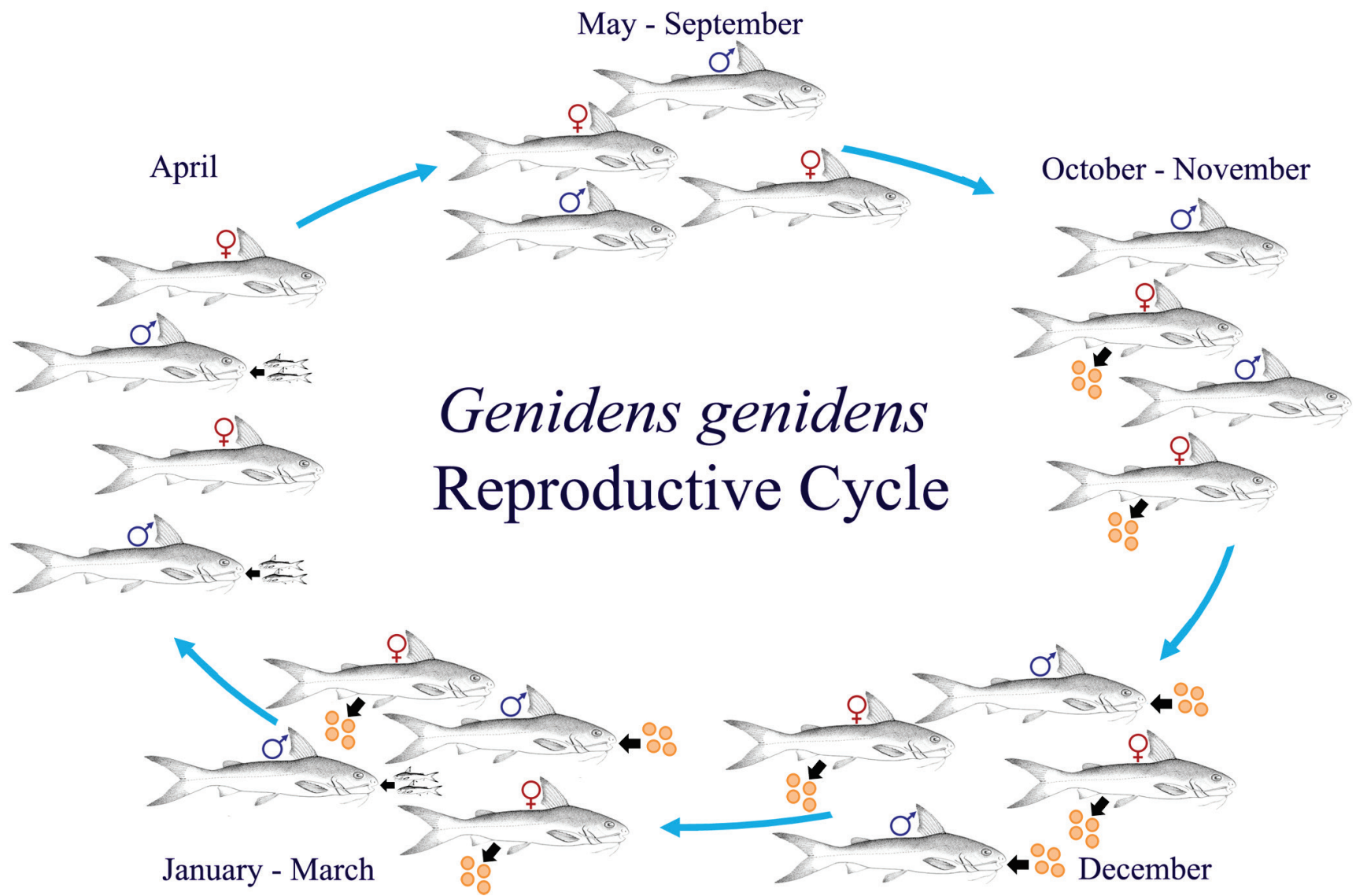

Fig. 5. Genidens genidens reproductive cycle in Guanabara Bay, Rio de Janeiro, Brazil. Fishes images are a modification of Fischer et al. (2011).

Tab. 1. Linear relationship between number and weight of offspring, and length and weight of Genidens genidens males in Guanabara Bay, Rio de Janeiro, Brazil.

\begin{tabular}{lccccc}
\hline \multicolumn{1}{c}{ Relationship } & \#offspring & \#males & $a$ & $b$ & $\mathrm{R}^{2}$ \\
\hline Total length of males - number of eggs & 106 & 10 & 0.1821 & 5.0107 & 0.0235 \\
Total weight of males - number of eggs & 106 & 10 & 0.0081 & 0.0237 \\
Total length of males - average weight of eggs & 106 & 10 & -0.0039 & 1.1814 \\
Total weight of males - average weight of eggs & 5 & 3 & -0.0003 & 1.1359 \\
Total length of males - number of juveniles & 5 & 3 & -0.1154 & 4.6667 \\
Total weight of males - number of juveniles & 5 & 3 & -0.0053 & 0.0081 \\
Total length of males - weight of juveniles & 5 & 3 & -0.1057 & 0.0210 \\
Total weight of males - weight of juveniles & 5 & 3 & -0.0055 & 4.1563 & 0.3620 \\
\hline
\end{tabular}

males tends to be higher, as observed by Barbieri et al. (1992) in Jacarepaguá Lagoon (Rio de Janeiro, Brazil) and by Hostim-Silva et al. (2009) in the mouth of the Itajaí-Açú River (Santa Catarina, Brazil). The authors do not relate this to a population attribute, but as result from the seasonal migration mainly of females to adjacent marine coastal areas, with males remaining longer in the estuary to incubate the eggs and juveniles. In our study, the number of females was higher than that of males during six months of the year and there was no difference in sex ratio in the other months, demonstrating that individuals from Guanabara Bay complete their life cycle within the estuary and do not migrate to adjacent regions.
The spawning season identified in the present study resulted from the biological coherence between the analyses of the monthly frequency of individuals with spawning-capable gonads and the mean values of the GSI and $\Delta \mathrm{K}$ indices. Dias et al. (1998) suggested that macroscopic analysis, since it is a simple and immediate classification, can be applied if it is accompanied by a previous survey of information on the reproductive biology of the species, an analysis of other indicators, such as quantitative indices, and a determination of the mean length of first gonadal maturation from microscopic analysis are also convenient. All these measures were adopted in the present study and supported the results of the 

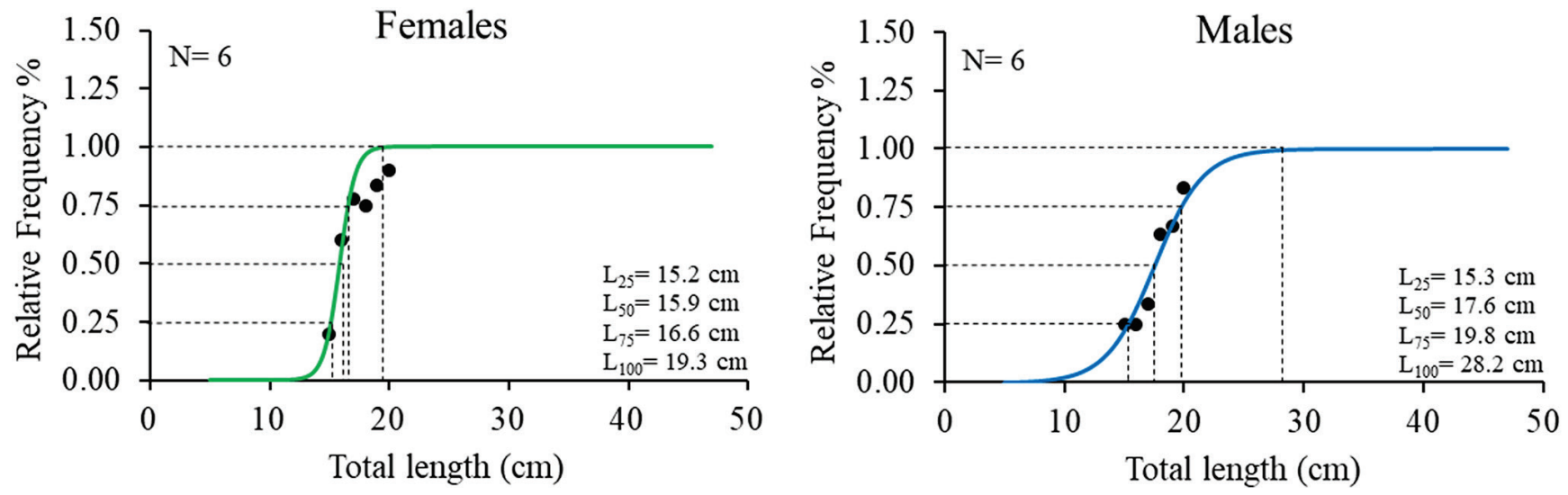

Fig. 6. Lengths of sexual maturation for males and females of Genidens genidens in Guanabara Bay, Rio de Janeiro, Brazil. Points are the observed values and the continuous line the calculated values.

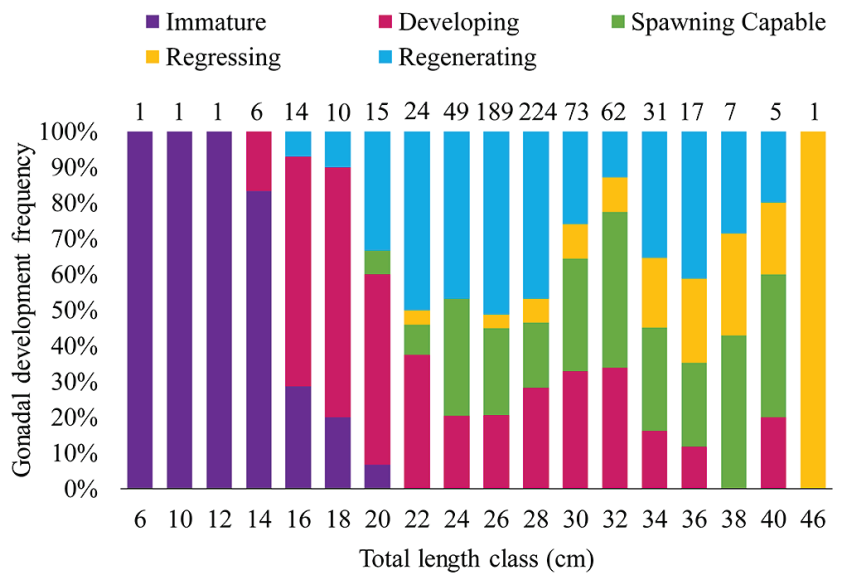

Fig. 7. Frequency of gonad development stages of Genidens genidens females $(\mathrm{N}=730)$ per total length class in Guanabara Bay, Rio de Janeiro, Brazil. There was no capture of females on lengths classes $8 \mathrm{~cm}, 42 \mathrm{~cm}$ and $44 \mathrm{~cm}$. The values at the top indicate the number of females caught in each length class.

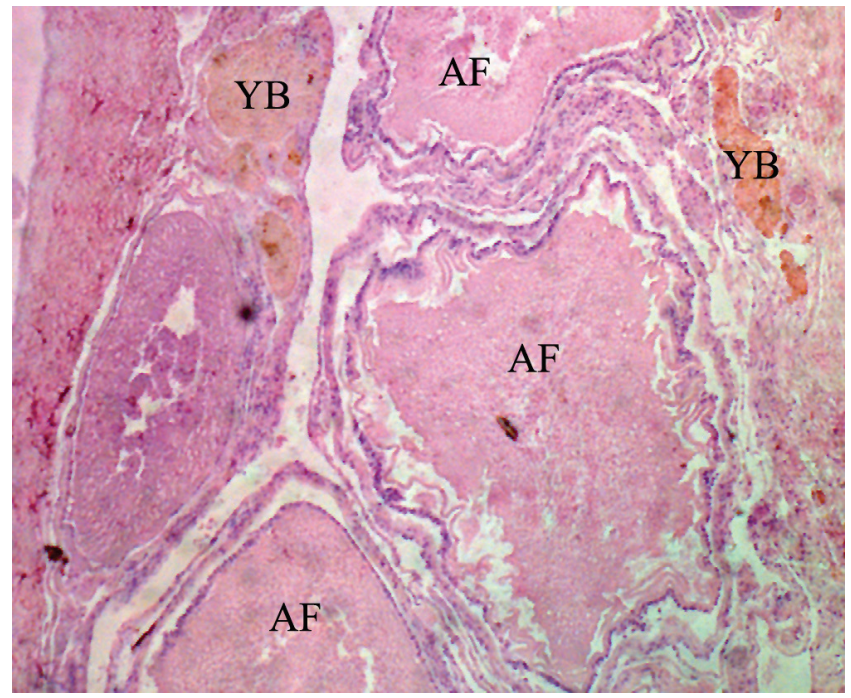

Fig. 8. Histological section of ovary of adult female smaller than $20 \mathrm{~cm}$ of Genidens genidens in Guanabara Bay, Rio de Janeiro, Brazil. Where: AF - atretic follicles; YB - yellow bodies.
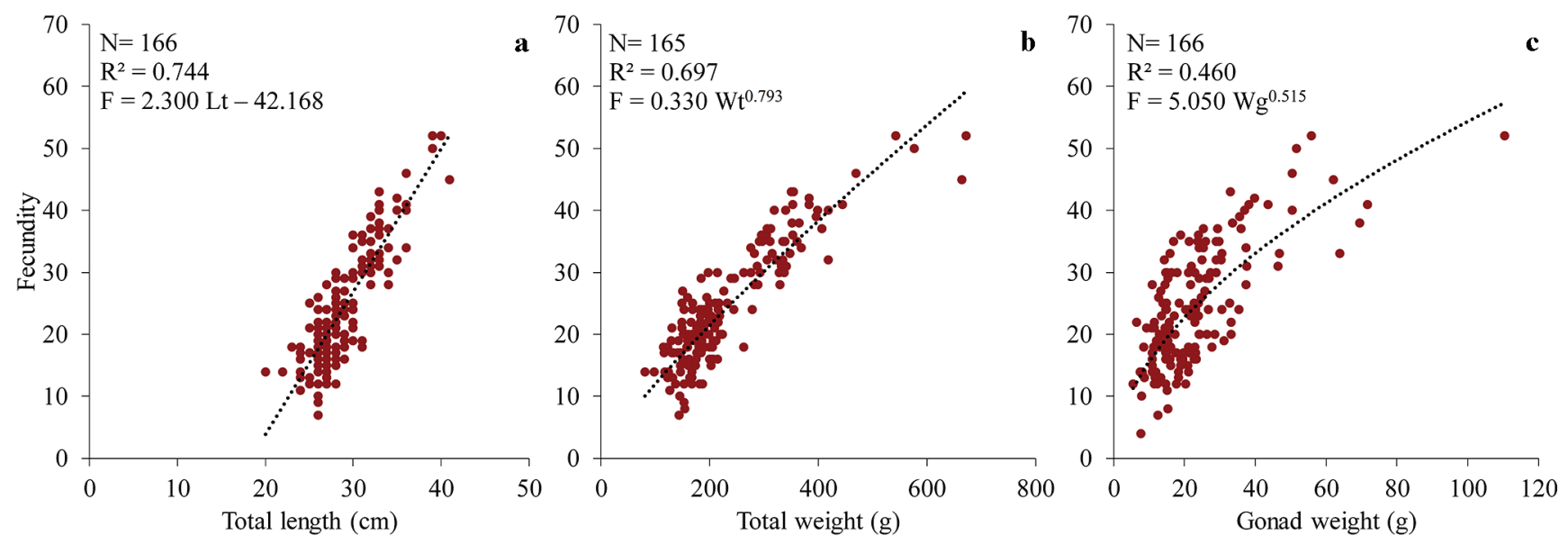

Fig. 9. Relationship between fecundity and $\mathbf{a}$. total length, b. total weight and c. gonad weight of Genidens genidens females, in Guanabara Bay, Rio de Janeiro, Brazil. 
macroscopic analysis. Criticisms of macroscopic classification of gonadal development stages, due to the subjectivity of the researcher in recognizing characteristics (e.g. Gomes, Araújo, 2004; Honji et al., 2006), are less important in the case of G. genidens, since the large size of the gonads, especially the ovaries, facilitates the visual diagnosis.

For $G$. genidens, the spawning period coincided with the warm months, beginning in spring (October) and extending into late summer (March), with a single annual spawning event. Similar information on G. genidens has been recorded in other areas along the Brazilian coast as Rio de Janeiro (Barbieri et al., 1992; Araújo et al., 1998; Mazzoni et al., 2000; Gomes, Araújo, 2004; Silva Junior et al., 2013), São Paulo (Mishima, Tanji, 1983; Schmidt et al., 2008) and Santa Catarina (Hostim-Silva et al., 2009), indicating that this is a general pattern for the species. In addition, the presence of individuals with developing gonads throughout the year suggests that a portion of the population is always prepared for a possible atypical reproduction (Hostim-Silva et al., 2009).

The peak reproductive period indicated by the GSI and $\Delta \mathrm{K}$ values was supported both by the frequency of gonads spawning-capable, and by other studies (e.g. Barbieri et al., 1992; Gomes, Araújo, 2004; Hostim-Silva et al., 2009). Both indices are indicative of reproduction (West, 1990) and reflect the amount of energy being directed toward it (Vazzoler, 1996). However, the values of GSI and $\Delta \mathrm{K}$ of males were much lower than those obtained for females, since much less energy need be allocated for sperm production than for oocytes, especially in species such as G. genidens that reproduce in closed environments with little tidal variation (Wootton, 1990). Despite this, an increase in these rates for males was apparent one month after the beginning of the increase observed for females, which may reflect a small delay in the beginning of reproductive activity of the males. Therefore, the values of GSI and $\Delta \mathrm{K}$ for the males are not good indicators of the reproductive period (Hostim-Silva et al., 2009).

The record of males carrying out oropharyngeal incubation was important, since their frequency of occurrence can also be used as indicator of the reproductive period of the species (Hostim-Silva et al., 2009). The incubation period of G. genidens occurred from early summer to early autumn, coinciding with the period during and soon after the peak frequency of females capable of spawning, as recorded by Barbieri et al. (1992) and Hostim-Silva et al. (2009).

Few males were captured while incubating eggs or juveniles, and fewer incubated eggs and juveniles were collected, compared to the results obtained by Barbieri et al. (1992), who obtained 53 males incubating, and by Silva Junior et al. (2013), with males incubating up to 34 eggs or juveniles. In addition, a linear increase in the number and weight of eggs and juveniles was expected as a function of the size of the males (Barbieri et al., 1992), but this was only observed for the weight of juveniles in Guanabara Bay. Chaves (1994) stated that in this species, larger adults incubate more eggs and juveniles, as well as larger juveniles, but did not find a similar relationship for egg weight. One possible explanation for the low number of incubating males caught is that these individuals do not feed when they are performing parental care (Chaves, 1994) and hide themselves, which reduces the chance of being caught. In addition, during capture, it is possible that males release the eggs and juveniles into the water as a last attempt to protect the offspring, which would explain the few eggs and juveniles sampled. This suggestion is based on the observation of males with an empty oral cavity but with the mandible dilated, which is indicative of incubation (Gomes et al., 1999; Paiva et al., 2015).

The mean lengths at first gonadal maturation $\left(\mathrm{L}_{50}\right)$ and the sizes in which all individuals are mature $\left(\mathrm{L}_{100}\right)$ recorded in the literature for $G$. genidens are quite dissimilar. Mishima, Tanji (1983) described $\mathrm{L}_{50}$ of $15.5 \mathrm{~cm}$ for females and 16 $\mathrm{cm}$ for males in the Cananéia estuary (São Paulo). Barbieri et al. (1992) found $\mathrm{L}_{50}$ of $18.0 \mathrm{~cm}$ and $\mathrm{L}_{100}$ of $25.0 \mathrm{~cm}$ for females in the Jacarepaguá Lagoon (Rio de Janeiro). Araújo et al. (1998) obtained the $\mathrm{L}_{50}$ of $13.3 \mathrm{~cm}$ and $16.0 \mathrm{~cm}$ and $\mathrm{L}_{100}$ of $16.0 \mathrm{~cm}$ and $18.5 \mathrm{~cm}$ for females and males, respectively, in Sepetiba Bay (Rio de Janeiro). Mazzoni et al. (2000) estimated the $\mathrm{L}_{50}$ of $5.5 \mathrm{~cm}$ for females and $8.5 \mathrm{~cm}$ for males in the Maricá Lagoon (Rio de Janeiro), while Hostim-Silva et al. (2009) recorded $\mathrm{L}_{50}$ and $\mathrm{L}_{100}$ of $13.4 \mathrm{~cm}$ and $21.3 \mathrm{~cm}$ for females and $16.8 \mathrm{~cm}$ and $23.9 \mathrm{~cm}$ for males at the mouth of the Itajaí-Açú River (Santa Catarina).

The calculated values in this study (Fig. 6) were, in general, higher than most of the values found in the literature for the species in other localities. Independently of small methodological differences in parameter estimation among studies, this variation could be explained by intraspecific genetic differences (Vazzoler, 1996). Different fishing pressures along the area of occurrence of the species may explain this variability, since they may trigger density-dependent compensatory changes (Trippel, 1995; Law, 2000; Lowerre-Barbieri, 2009). Selective capture leads to changes in the evolutionary regime, causing a decrease in the first-maturation size, due to plastic responses resulting from the decreased competition for food, leading to faster growth, and genetic responses resulting from greater survival of individuals that tend to mature at a smaller body size, to the detriment of individuals that mature later, since early-maturing individuals are more likely to reproduce before being captured, thus increasing their genetic contribution to the population (Law, 2000; Roos et al., 2006). Therefore, the relatively small sizes at first maturation estimated by the other studies may indicate a decrease in stock sizes (Trippel, 1995). At the same time, Maciel et al. (2018) showed that G. genidens from Guanabara Bay reach older ages, suggesting that this population is more stable, with more size classes. This variation primarily shows that, although the calculated values are important references, they can change due to fishing pressure and therefore should not be used as a static reference (Lowerre-Barbieri, 2009).

In Guanabara Bay, the high values of $\mathrm{L}_{50}$ and $\mathrm{L}_{100}$ indicate later maturity, allowing individuals to reach larger sizes 
by allocating more energy to growth for longer periods. This will increase fecundity, in females due to the larger space in the abdominal cavity, and in males due to the larger space in their oral cavity to carry more juveniles (Mazzoni et al., 2000; Paiva et al., 2015). In all regions where the reproductive biology of $G$. genidens has been studied, the $\mathrm{L}_{50}$ and $\mathrm{L}_{100}$ values of males are always higher than those of females (Barbieri et al., 1992; Araújo et al., 1998; Mazzoni et al., 2000; Hostim-Silva et al., 2009), showing that males reach sexual maturity at a larger size than females, a sexual dimorphism inherent to the species (Hostim-Silva et al., 2009). This dimorphism was also evident in the analysis of morphometry of the head of adult males (Paiva et al., 2015) and in the growth of the species (Maciel et al., 2018).

The results also suggest that $G$. genidens females are skipping spawning. The skipped-spawning strategy is defined as postponement of spawning for the following year, with no negative consequences for future reproduction (Rideout, Tomkiewicz, 2011). This plastic response is modeled as a trade-off between current and future reproduction (Rideout et al., 2005). Skipping spawning may have advantages for survival and growth of individuals in the current year, to maximize their reproductive success in later years (Secor, 2008).

Adult females of $G$. genidens had gonads classified as spawning-capable only from $20 \mathrm{~cm}$ and larger. The presence of atretic follicles and yellow bodies in the ovaries of adult females smaller than $20 \mathrm{~cm}$ showed that they are reabsorbing their oocytes (Miranda et al., 1999; Santos et al., 2008; Rideout, Tomkiewicz, 2011). This suggests that these young individuals are skipping spawning as an adaptive strategy, which allows greater investment in growth to increase their fertility in later years (Rideout et al., 2005; Jørgensen et al., 2006; Folkvord et al., 2014). Jørgensen et al. (2006), who studied skipped spawning in Gadus morhua (Linnaeus, 1758), and Rideout, Tomkiewicz (2011), that reviewed skipping spawning in several species, showed that it is more common in the first years after maturation. The reason is that reproduction costs are disproportionately higher for young individuals that are reproducing for the first time (Secor, 2008). For G. genidens the probable reason is that the number of eggs produced is limited both by the quantity of resources for oocyte production and by the space available for eggs in the females' body cavity (Barbieri et al., 1992; Gomes, Araújo, 2004; Pandian, 2010), since species from the family Ariidae produces the largest oocytes among teleosts (Wallace, Selman, 1981).

The recorded fecundity for G. genidens in Guanabara Bay (8-52 oocytes) is low in comparison to other teleosts. However, it is higher than that observed by other authors for the species: 7-30 (Barbieri et al., 1992), 13-24 (Gomes et al., 1999), 6-24 (Gomes, Araújo, 2004) and 7-38 oocytes (Schmidt et al., 2008). This can be explained by the large specimens captured in our study, since larger females are more fecund (Palumbi, 2004). Our results also showed that the fecundity of the species was linearly correlated with length, proving this positive relationship between the size of the females and the increase of the fecundity. Barbieri et al. (1992) stated that although the fecundity in teleosts is generally expressed as a potential relationship with length, the linear relationship in G. genidens is in agreement with observations for other ariids, due to their large oocytes (Wallace, Selman, 1981). Therefore, a cubic increase in fecundity would be limited by the space in the abdominal cavity of females, as well as by the energy available to produce oocytes. Although the fecundity showed a potential correlation with weight increase, as expected, the same did not occur for gonadal increase.

Studies on the reproduction of G. genidens are highly important for the conservation of the species, since for effective management it is essential to understand the reproductive processes of the exploited stocks and the effects of these processes on recruitment (Lowerre-Barbieri, 2009; Lowerre-Barbieri et al., 2015, 2016). Although Guanabara Bay is one of the most degraded estuarine ecosystems on the Brazilian coast (Meniconi et al., 2012), it supports intense fishing activity (Prestrelo, Vianna, 2016) in which this species is widely caught. In this study, the number of specimens caught was high and the reproductive characteristics of the species, such as time and type of spawning, as well as size at first maturation and fecundity of the females, do not seem to be affected by anthropic pressures. These results corroborate the high tolerance of $G$. genidens to adverse environmental conditions, reported by Silva Junior et al. (2013) showing that this population has high reproductive resilience, considering its capacity to maintain reproductive success, resulting in its long-term stability, despite disturbances such as environmental degradation and fishing pressure (LowerreBarbieri et al., 2015, 2016).

Although its apparent resistance to adverse conditions, low fecundity coupled with intensive parental care make this catfish quite susceptible to population decreases due to fishing pressure. Its vulnerability has already been recognized nationally, generating fishing-regulation measures for São Paulo State and for the southern coast of Brazil, defining the closed-season and minimum catch size (MMA, 2004; SUDEPE, 1984). However, despite its importance in the regional fishery (Silva Junior et al., 2013), there is no management measure for the ariid fishery in Guanabara Bay, nor specifically for G. genidens, as well as in all the regulations promulgated by the state of Rio de Janeiro (Begot, Vianna, 2014). Therefore, considering that the resilience of a stock is directly connected to factors related to its reproductive success (Lowerre-Barbieri, 2009), the results obtained by this study produced important supporting information for the management of the species. We propose the following restrictive measures for the G. genidens commercial fishery: (1) establish a minimum catch size of $20 \mathrm{~cm}$, considering the $\mathrm{L}_{75}$ of males and the better consumer acceptance of larger fish; (2) total fishing prohibition during a closed-season from December through March, to include the reproductive peak and the main period of oropharyngeal incubation. Im- 
plementation of these two measures will contribute significantly to the conservation of the species, and this strategy can be replicated in the other estuaries and areas of occurrence of this catfish.

\section{Acknowledgments}

The authors thank the Laboratório de Biologia e Tecnologia Pesqueira/UFRJ team for their help in the samplings, in the processing of the material, and in the discussions, especially Sérgio Santos and Luana Prestrelo. We are also grateful to Sérgio Teixeira from the Laboratório de Ecologia de Peixes/UFRJ, for his help in the preparation of histological slides, and to the artisanal fishermen for their participation in obtaining biological material. Finally, we thank the CNPq (MV, AMVS and TRM) and FAPERJ (MV) for the research grants and studentships, and the PELD-Baía de Guanabara (CNPq PELD 403809/2012-6) and FAPERJ (E26/112.636/2012, E26/110.114/2013 and E26/201.334/2014) for financial support. Janet W. Reid (JWR Associates) revised the English text.

\section{References}

Acero A. Order Siluriformes: Ariidae - Sea catfishes. In: Carpenter $\mathrm{KE}$, editor. Bony fishes part 1 (Acipenseridae to Grammatidae). Rome: Food and Agriculture Organization of the United Nations (FAO); 2002. (FAO species identification guide for fishery purposes. The living marine resources of the Western Central Atlantic; vol. 2). p.831-858. Available from: http:// www.fao.org/docrep/pdf/009/y4161e/y4161e17.pdf

Andrade AC, Santos SR, Verani JR, Vianna M. Guild composition and habitat use by Tetraodontiformes (Teleostei, Acanthopterygii) in a south-western Atlantic tropical estuary. J Mar Biol Assoc U K. 2015; 96(6):1251-64. Available from: http://dx.doi.org/10.1017/S0025315415001368

Andrade-Tubino MF, Ribeiro ALR, Vianna M. Organização espaçotemporal das ictiocenoses demersais nos ecossistemas estuarinos brasileiros: uma síntese. Oecol Bras. 2008; 12(4):640-61. Available from: http://dx.doi.org/10.4257/oeco.2008.1204.05

Araújo FG. Distribuição, abundância relativa e movimentos sazonais de bagres marinhos (Siluriformes, Ariidae) no estuário da Lagoa dos Patos (RS), Brasil. Rev Bras Zool. 1988; 5(4):509-43. Available from: http://dx.doi.org/10.1590/S010181751988000400002

Araújo FG, Gomes ID, Azevedo MCC, Pessanha ALM. Maturação e desova do bagre marinho Genidens genidens Valenciennes, 1833 (Siluriformes, Ariidae), na Baía de Sepetiba, RJ. Acta Biol Leopold. 1998; 20(1):109-22.

Azevedo MCC, Araújo FG, Cruz-Filho AG, Gomes ID, Pessanha ALM. Variação espacial e temporal de bagres marinhos (Siluriformes, Ariidae) na Baía de Sepetiba, Rio de Janeiro. Rev Bras Biol. 1999; 59(3):443-54. Available from: http:// dx.doi.org/10.1590/S0034-71081999000300009

Barbieri LR, Santos RP, Andreata JV. Reproductive biology of the marine catfish, Genidens genidens (Siluriformes, Ariidae), in the Jacarepaguá Lagoon system, Rio de Janeiro, Brazil. Environ Biol Fishes. 1992; 35(1):23-35. Available from: http:// dx.doi.org/10.1007/BF00001154

Begot LH, Vianna M. Legislação pesqueira costeira: o caso da Baía de Guanabara, RJ. Bol Inst Pesca. 2014; 40(4):497-520.
Blaber SJM. Fishes and fisheries in tropical estuaries: the last 10 years. Estuar Coast Shelf Sci. 2013; 135:57-65. Available from: http://dx.doi.org/10.1016/j.ecss.2012.11.002

Brown-Peterson NJ, Wyanski DM, Saborido-Rey F, Macewicz BJ, Lowerre-Barbieri SK. A Standardized terminology for describing reproductive development in fishes. Mar Coast Fish. 2011; 3(1):52-70. Available from: http://dx.doi.org/10.1080/19 425120.2011.555724

Castro MS, Bonecker ACT, Valentin JL. Seasonal variation in fish larvae at the entrance of Guanabara Bay, Brazil. Braz Arch Biol Technol. 2005; 48(1):121-28. Available from: http://dx.doi. org/10.1590/S1516-89132005000100016

Chaves PTC. A incubação de ovos e larvas em Genidens genidens (Valenciennes) (Siluriformes, Ariidae) da Baía de Guaratuba, Paraná, Brasil. Rev Bras Zool. 1994; 11(4):641-48. Available from: http://dx.doi.org/10.1590/S0101-81751994000400008

Corrêa B, Vianna M. Spatial and temporal distribution patterns of the silver mojarra Eucinostomus argenteus (Perciformes: Gerreidae) in a tropical semi-enclosed bay. J Fish Biol. 2016; 89(1):641-60. Available from: http://dx.doi.org/10.1111/jfb.12843

Dias JF, Peres-Rios E, Chaves PTC, Rossi-Wongtschowski CLB. Análise macroscópica dos ovários de teleósteos: problemas de classificação e recomendações de procedimentos. Rev Bras Biol. 1998; 58(1):55-69.

Elliott M, Whitfield AK, Potter IC, Blaber SJM, Cyrus DP, Nordlie FG, Harrison TD. The guild approach to categorizing estuarine fish assemblages: a global review. Fish Fish. 2007; 8(3):241-68. Available from: http://dx.doi.org/10.1111/j.14672679.2007.00253.x

Fischer LG, Pereira LED, Vieira JP. Peixes estuarinos e costeiros. 2nd ed. Rio Grande: Luciano Gomes Fischer; 2011.

Folkvord A, Jørgensen C, Korsbrekke K, Nash RDM, Nilsen T, Skjæraasen JE. Trade-offs between growth and reproduction in wild Atlantic cod. Can J Fish Aquat Sci. 2014; 71(7):1106-12. Available from: http://dx.doi.org/10.1139/cjfas-2013-0600

Gomes ID, Araújo FG, Azevêdo MCC, Pessanha ALM. Biologia reprodutiva dos bagres marinhos Genidens genidens (Valenciennes) e Cathorops spixii (Agassiz) (Siluriformes, Ariidae), na Baía de Sepetiba, Rio de Janeiro, Brasil. Rev Bras Zool. 1999; 16(Suppl.2):171-80. Available from: http://dx.doi. org/10.1590/S0101-81751999000600017

Gomes ID, Araújo FG. Reproductive biology of two marine catfishes (Siluriformes, Ariidae) in the Sepetiba Bay, Brazil. Rev Biol Trop. 2004; 52(1):143-56. Available from: http://www.scielo. sa.cr/scielo.php?pid = S0034-77442004000100020\&script $=$ sci arttext

Honji RM, Vaz-dos-Santos AM, Rossi-Wongtschowski CLB. Identification of the stages of ovarian maturation of the Argentine hake Merluccius hubbsi Marini, 1933 (Teleostei: Merlucciidae): advantages and disadvantages of the use of the macroscopic and microscopic scales. Neotrop Ichthyol. 2006; 4(3):329-37. Available from: http://dx.doi.org/10.1590/S167962252006000300004

Hostim-Silva M, Verani JR, Branco JO, Leite JR. Reprodução do bagre Genidens genidens (Siluriformes, Ariidae) na foz do Rio Itajaí-Açú, SC. In: Branco JO, Lunardon-Branco MJ, Bellotto VR, organizers. Estuário do rio Itajaí-Açú, Santa Catarina: caracterização ambiental e alterações antrópicas. Itajaí: Editora UNIVALI; 2009. p.279-298.

Jørgensen C, Ernande B, Fiksen Ø, Dieckmann U. The logic of skipped spawning in fish. Can J Fish Aquat Sci. 2006; 63(1):20011. Available from: http://dx.doi.org/10.1139/f05-210 
Kailola PJ. Order Siluriformes: Ariidae (= Tachysuridae) - Sea catfishes (fork-tailed catfishes). In: Carpenter KE, Angelis $\mathrm{N}$, editors. Batoid fishes, chimaeras and bony fishes part 1 (Elopidae to Linophrynidae). Rome: Food and Agriculture Organization of the United Nations (FAO); 1999. (FAO species identification guide for fishery purposes, The Living Marine Resources of the Western Central Pacific; vol. 3) p.1827-79. Available from: http://www.fao.org/docrep/pdf/009/x2401e/ x2401e33.pdf

King MG. Fisheries biology, assessment and management. Oxford: Blackwell Science Ltd.; 1995.

Kjerfve B, Ribeiro CHA, Dias GTM, Filippo AM, Quaresma VS. Oceanographic characteristics of an impacted coastal bay: Baía de Guanabara, Rio de Janeiro, Brazil. Cont Shelf Res. 1997; 17(13):1609-43. Available from: http://dx.doi.org/10.1016/ S0278-4343(97)00028-9

Law R. Fishing, selection, and phenotypic evolution. ICES J Mar Sci. 2000; 57(3):659-68. Available from: http://dx.doi. org/10.1006/jmsc.2000.0731

Lowerre-Barbieri SK. Reproduction in relation to conservation and exploitation of marine fishes. In: Jamieson BGM, editor. Reproductive biology and phylogeny of fishes (Agnathans and Bony Fishes). Enfield: CRC Press; 2009. (Reproductive Biology and Phylogeny; vol. 8B). p.371-394.

Lowerre-Barbieri S, Crabtree L, Switzer T, Burnsed SW, Guenther C. Assessing reproductive resilience: an example with South Atlantic red snapper Lutjanus campechanus. Mar Ecol Prog Ser. 2015; 526:125-41. Available from: http://dx.doi. org/10.3354/meps 11212

Lowerre-Barbieri S, DeCelles G, Pepin P, Catalán IA, Muhling B, Erisman B, Cadrin SX, Alós J, Ospina-Alvarez A, Stachura MM, Tringali MD, Burnsed SW, Paris CB. Reproductive resilience: a paradigm shift in understanding spawner-recruit systems in exploited marine fish. Fish Fish. 2016; 18(2):285312. Available from: http://dx.doi.org/10.1111/faf.12180

Maciel TR, Vaz-dos-Santos AM, Vianna, M. Can otoliths of Genidens genidens (Cuvier 1829) (Siluriformes: Ariidae) reveal differences in life strategies of males and females? Environ Biol Fishes. 2018. Available from: https://doi.org/10.1007/ s10641-018-0804-5

Marceniuk AP, Menezes NA. Systematics of the family Ariidae (Ostariophysi, Siluriformes), with a redefinition of the genera. Auckland: Magnolia Press; 2007. (Zootaxa; 1416).

Mazzoni R, Petito J, Miranda JC. Reproductive biology of Genidens genidens, a catfish from the Maricá lagoon, RJ. Ciência e Cultura Journal of Brazilian Association for the Advancement of Science. 2000; 52(2):121-26.

Meniconi MFG, Silva TA, Fonseca ML, Lima SOF, Lima EFA, Lavrado HP, Figueiredo-Jr AG, editors. Baía de Guanabara: síntese do conhecimento ambiental - v. 2. Biodiversidade. Rio de Janeiro: PETROBRÁS; 2012.

Ministério do Meio Ambiente (MMA). Instrução Normativa MMA $\mathrm{N}^{\circ} 17$, de 17 de outubro de 2004. Brasília: Diário Oficial da União; 2004.

Miranda ACL, Bazzoli N, Rizzo E, Sato Y. Ovarian follicular atresia in two teleost species: a histological and ultrastructural study. Tissue Cell. 1999; 31(5):480-88. Available from: http:// dx.doi.org/10.1054/tice.1999.0045

Mishima M, Tanji S. Maturação e desova dos bagres marinhos (Osteichthyes, Ariidae) do complexo estuarino lagunar de Cananéia $\left(25^{\circ} \mathrm{S}, 48^{\circ} \mathrm{W}\right)$. Bol InstPesca. 1983; 10:129-41.Available from: ftp://ftp.sp.gov.br/ftppesca/sumario_10_129-141.pdf
O'Farrell MR, Botsford LW. The fisheries management implications of maternal-age-dependent larval survival. Can J Fish Aquat Sci. 2006; 63(10):2249-58. Available from: http://dx.doi.org/10.1139/f06-130

Paiva LG, Prestrelo L, Anna KMS, Vianna M. Biometric sexual and ontogenetic dimorphism on the marine catfish Genidens genidens (Siluriformes, Ariidae) in a tropical estuary. Lat Am J Aquat Res. 2015; 43(5):895-903.

Palumbi SR. Why mothers matter. Nature. 2004; 430:621-22. Available from: http://dx.doi.org/10.1038/430621a

Pandian TJ. Sexuality in fishes. Enfield: Science Publishers \& CRC Press; 2010.

Prestrelo L, Vianna M. Identifying multiple-use conflicts prior to marine spatial planning: a case study of a multi-legislative estuary in Brazil. Mar Policy. 2016; 67:83-93. Available from: http://dx.doi.org/10.1016/j.marpol.2016.02.001

Rideout RM, Rose GA, Burton MPM. Skipped spawning in female iteroparous fishes. Fish Fish. 2005; 6(1):50-72. Available from: http://dx.doi.org/10.1111/j.1467-2679.2005.00174.x

Rideout RM, Tomkiewicz J. Skipped spawning in fishes: more common than you might think. Mar Coast Fish. 2011; 3(1):176-89. Available from: http://dx.doi.org/10.1080/1942 5120.2011 .556943

Roos AM, Boukal DS, Persson L. Evolutionary regime shifts in age and size at maturation of exploited fish stocks. Proc R Soc B Biol Sci. 2006; 273(1596):1873-80. Available from: http://dx.doi.org/10.1098/rspb.2006.3518

Santos HB, Thomé RG, Arantes FP, Sato Y, Bazzoli N, Rizzo E. Ovarian follicular atresia is mediated by heterophagy, autophagy, and apoptosis in Prochilodus argenteus and Leporinus taeniatus (Teleostei: Characiformes). Theriogenology. 2008; 70(9):1449-60. Available from: http://dx.doi.org/10.1016/j.theriogenology.2008.06.091

Schmidt TCS, Martins IA, Reigada ALD, Dias JF. Taxocenose de bagres marinhos (Siluriformes, Ariidae) da região estuarina de São Vicente, SP, Brasil. Biota Neotrop. 2008; 8(4):7381. Available from: http://dx.doi.org/10.1590/S167606032008000400006

Secor DH. Influence of skipped spawning and misspecified reproductive schedules on biological reference points in sustainable fisheries. Trans Am Fish Soc. 2008; 137(3):78289. Available from: http://dx.doi.org/10.1577/T07-105.1

Silva Junior DR, Carvalho DMT, Vianna M. The catfish Genidens genidens (Cuvier, 1829) as a potential sentinel species in Brazilian estuarine waters. J Appl Ichthyol. 2013; 29(6):1297-303. Available from: http://dx.doi.org/10.1111/ jai. 12280

Silva Junior DR, Paranhos R, Vianna M. Spatial patterns of distribution and the influence of seasonal and abiotic factors on demersal ichthyofaunal in an estuarine tropical bay. J Fish Biol. 2016; 89(1):821-46. Available from: http://dx.doi. org/10.1111/jfb.13033

Stearns SC. The evolution of life histories. Oxford: Oxford University Press; 1992.

Superintendência de Desenvolvimento da Pesca (SUDEPE). Portaria SUDEPE N N-42, 18 de outubro de 1984. Brasília: Diário Oficial da União; 1984.

Trippel EA. Age at maturity as a stress indicator in fisheries: biological processes related to reproduction in northwest Atlantic groundfish populations that have undergone declines. Bioscience. 1995; 45(11):759-71. Available from: http://dx.doi.org/10.2307/1312628 
Vazzoler AEAM. Biologia da reprodução de peixes teleósteos: teoria e prática. Maringá: EDUEM; 1996.

Wallace RA, Selman K. Cellular and dynamic aspects of oocyte growth in teleosts. Am Zool. 1981; 21(2):325-43. Available from: http://dx.doi.org/10.1093/icb/21.2.325

West G. Methods of assessing ovarian development in fishes: a review. Aust J Mar Freshw Res. 1990; 41(2):199-222. Available from: http://dx.doi.org/10.1071/MF9900199

Wootton RJ. Ecology of teleost fishes. New York: Chapman and Hall; 1990.
Zar JH. Biostatistical analysis. 5th ed. Upper Saddle River (NJ): Prentice Hall; 2010.
Submitted September 27, 2017

Accepted September 25, 2018 by Andrea Bialetzki 